AGH DRILLING, OIL, GAS • Vol. 35 • No. $1 \cdot 2018$

http://dx.doi.org/10.7494/drill.2018.35.1.323

Magdalena Gaczoł*, Sławomir Wysocki*, Karina Budzińska*

\title{
MODIFICATIONS OF THE MUDS INTENDED FOR HDD CONSIDERING DRILLING THROUGH CLAY ROCKS - POTASSIUM CHLORIDE**
}

\section{INTRODUCTION}

Popularity of Horizontal Directional Drilling (HDD) technique is rapidly growing. It is a trenchless technology involving performance of pipelines or optical fibre under obstacles in form of river, railway and road infrastructure etc. There are numerous advantages of HDD, such as decreased interference in environment as well as in infrastructure, reduction of disturbances for developed areas and assurance of rapid work progress [1].

Stability of borehole wall is one of main functions of drilling mud. It is connected to type of drilled rock. One of the most problematic rocks in drilling industry is clay rock. Moreover, this kind of a formation is most abundant rock drilled in the world $(75 \%$ of drilled formations) [2]. Various difficulties occur in case of clays encounter, due to its specific properties which are a consequence of its structure [xx]. In view of the drilling process the most important characteristic of clays is its tenderness to physical changes dependent on the amount of water. Its volume can increase even up to 20 times its size when exposed to water [3].

While clay minerals swell, often also becomes gluey. Thus, they may accelerate on the drill bit and slow down ROP [4] creating "clay ball” on the drill bit (bit balling - Fig. 1) and tightening of the borehole diameter. Moreover, swelled clays in most unfortunate

* AGH University of Science and Technology, Faculty of Drilling, Oil and Gas, Krakow, Poland

** The work realized within statutory research program of Faculty of Drilling, Oil and Gas AGH UST no. 11.11.190.555 
circumstances may cause stuck of the pipe in the borehole (Fig. 2), hence create long and expensive breaks in the drilling process. It is important to avoid such situations from the beginning, for once it happens, the return to the initial conditions is impossible. The only approach in abovementioned cases is to reduce caused damage or abandon of the borehole.

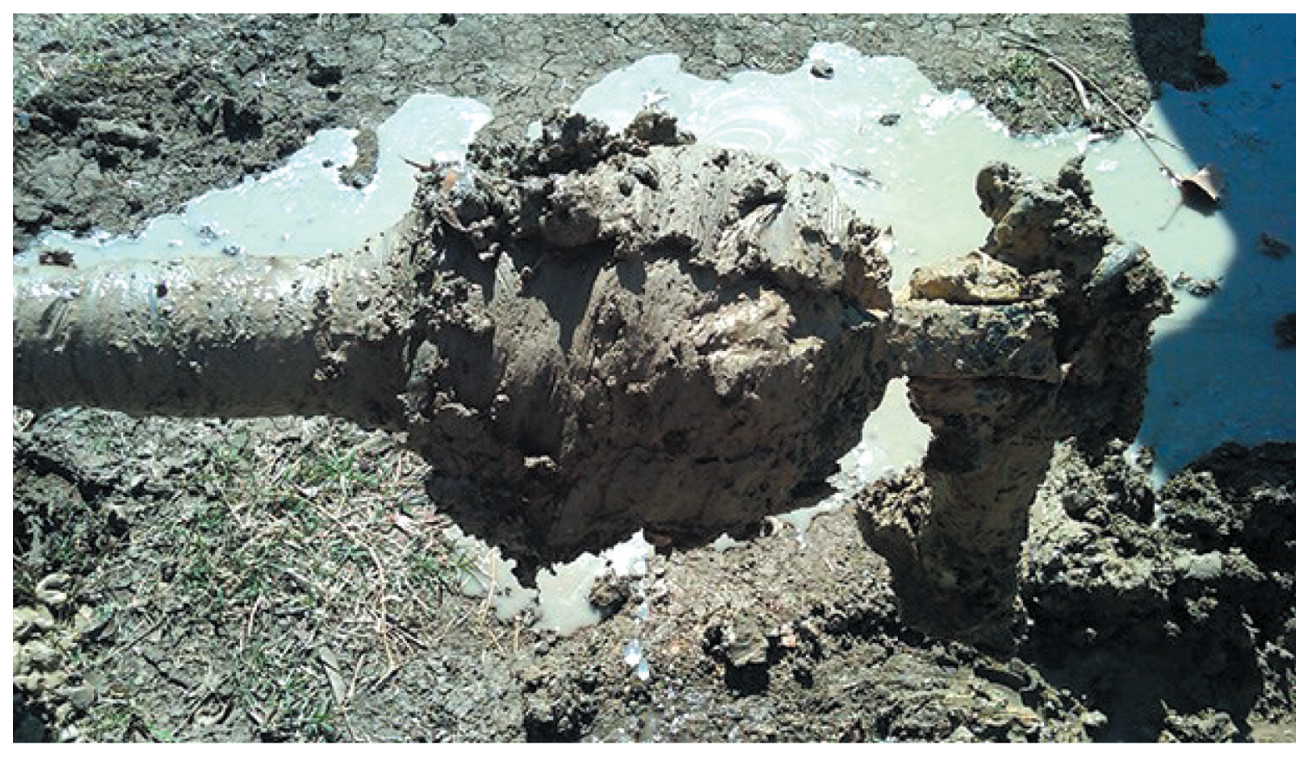

Fig. 1. Drill bit balled up with swelled clays [5]

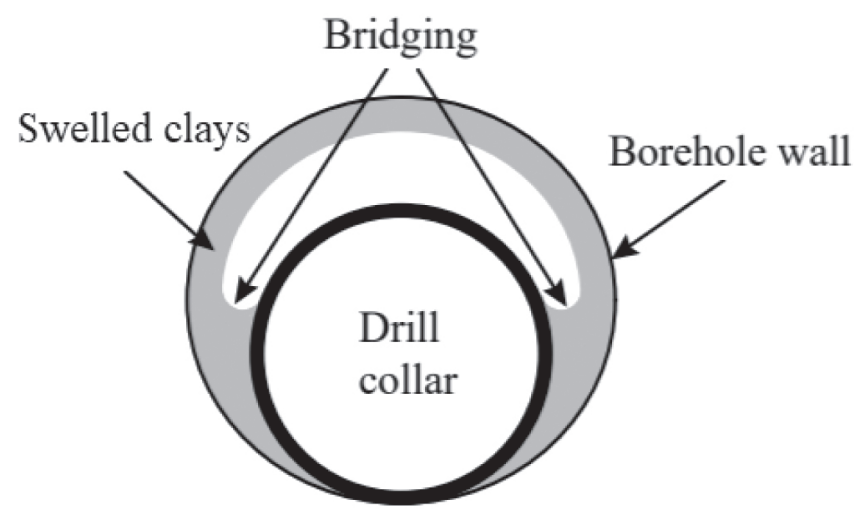

Fig. 2. Pipe stuck in swelled clay rock [6]

Therefore, type of the mud should be carefully selected in light of the drilled formation. Regardless of mentioned facts, those rocks are drilled mainly with water-based 
muds what can lead to excessive hydration of the clays. The most effective procedure in case of clays encounter is application of the hydration inhibitor. Those are chemical substances that decrease hydration phenomena in clay minerals. There can be distinguished different types of the inhibitors: cationic, anionic and nonionic [7]. Potassium chloride, as a cationic inhibitor, is a common representative of such substances. Thanks to the potassium ion $\left(\mathrm{K}^{+}\right)$dissolved in the water-based mud, clay swelling can be diminished. Ion exchange allows placement of $\mathrm{K}^{+}$ions in interlayer surface of clay mineral [8]. The fact that those ions do not hydrate results in limitation of water migration into interlayer surface of clay mineral [7]. Moreover, cuttings are held together more effectively by minimization of dispersion phenomenon [8].

\section{METHODOLOGY OF THE RESEARCH}

Preparation of the muds: muds for HDD were mixed with water for $10 \mathrm{~min}$, afterwards protective colloid was added and mud was mixed for 15 min, afterwards hydration inhibitor was added and mud was mixed for $5 \mathrm{~min}$.

The surveys were performed according to international standards API Spec. [9]. Rheological models of the muds were prepared with Rheosolution computer application developed on the Faculty of Drilling, Oil and Gas AGH University of Science and Technology in Krakow [10].

Linear swelling tests have been achieved with GRACE Instrument M4600 HPHT Linear Swell Meter; sample was conditioned in the mud for $20 \mathrm{~h}$. Clay material used for tests was collected from boreholes drilled by HDD technique.

QSE Pellets swelling tests: clay pellet was measured and its initial volume was calculated, then pellets was immersed in studied mud for $24 \mathrm{~h}$, after this period of time pellet was measured again and its final volume was calculated. Furthermore, consistency and glutinosity of pellets were assessed after test.

\section{MATERIALS USED IN THE RESEARCH}

HDD Mud 2 - mud intended for HDD, used in the industrial practice; CMS - carboxymethyl starch, supplier: EXALO DRILLING S.A.; XCD - biopolymer, xanthan gum, supplier: EXALO DRILLING S.A.; PAC LV - low viscosity polyanionic cellulose, supplier: EXALO DRILLING S.A.; $\mathrm{KCl}$ - potassium chloride, supplier: Avantor Performance Materials Poland S.A. 


\section{TESTS OF BASE MUDS}

Tests of technological parameters of the HDD Mud 2 in concentrations of $2.5-4.0 \% \mathrm{w} / \mathrm{w}$ were conducted. Results are presented in Figure 3.
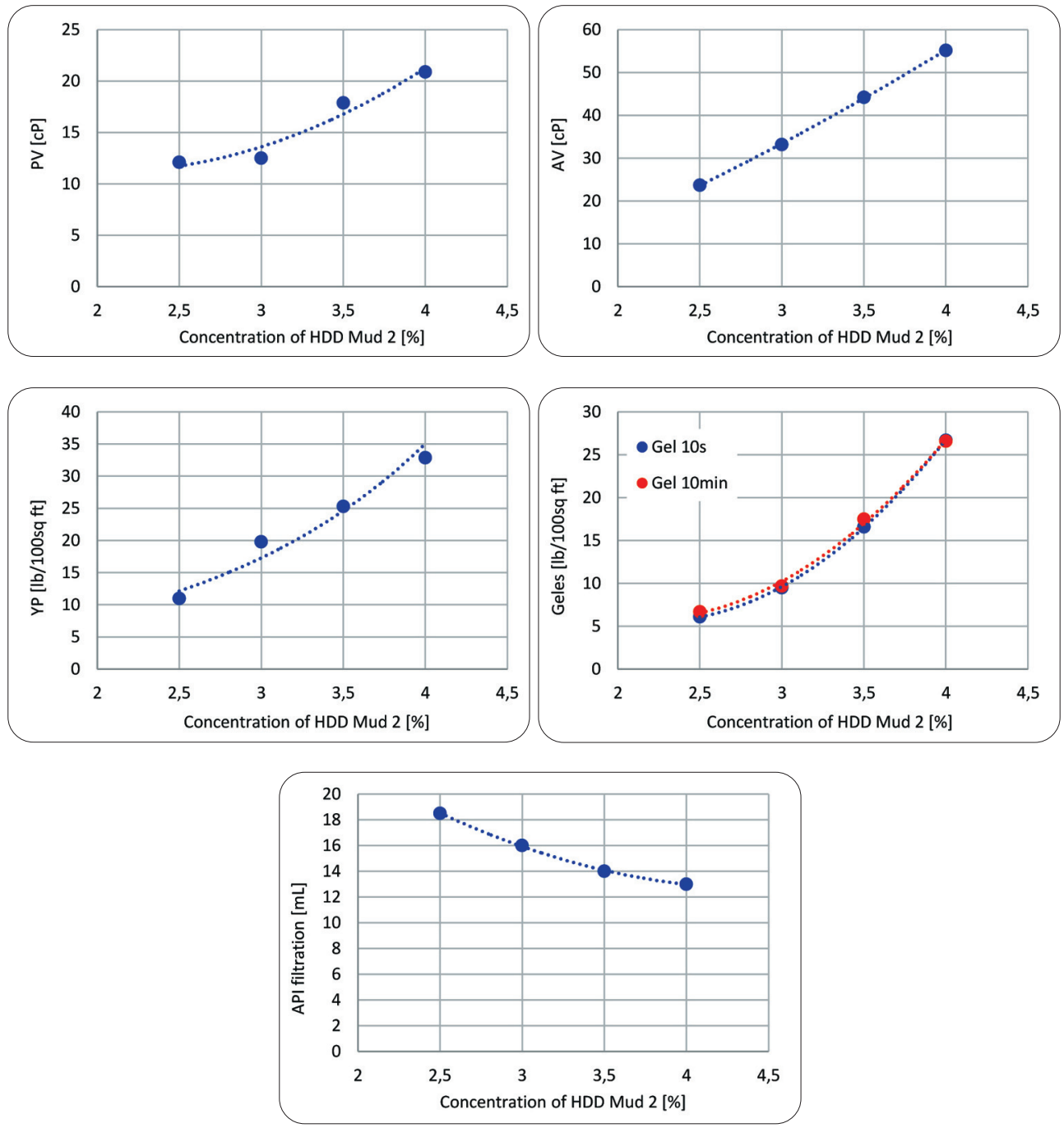

Fig. 3. Dependence of HDD Mud 2 technological parameters on its concentration

For further studies HDD Mud 2 with concentration of $4.0 \% \mathrm{w} / \mathrm{w}$ was selected. Its technological parameters are given in Table 1. Subsequently, rheological model for the chosen mud was prepared - Figure 4. 
Table 1

Formula and technological parameters of the HDD Mud 2 with $4 \%$ concentration $(\mathrm{w} / \mathrm{w})$

\begin{tabular}{|c|c|c|c|c|}
\hline Mud H & $2-1$ & \multicolumn{3}{|c|}{ Technological parameters } \\
\hline \multirow{6}{*}{ HDD Mud 2} & \multirow{6}{*}{$4.0 \%$} & Density & 1.05 & {$\left[\mathrm{~g} / \mathrm{cm}^{3}\right]$} \\
\hline & & Plastic viscosity & 20.9 & {$[\mathrm{cP}]$} \\
\hline & & Apparent viscosity & 55.2 & {$[\mathrm{cP}]$} \\
\hline & & Yield Point & 32.9 & {$\left[\mathrm{lb} / 100 \mathrm{ft}^{2}\right]$} \\
\hline & & Geles & $26.6 / 26.7$ & {$\left[\mathrm{lb} / 100 \mathrm{ft}^{2}\right]$} \\
\hline & & API filtration & 13 & {$[\mathrm{~mL}]$} \\
\hline
\end{tabular}

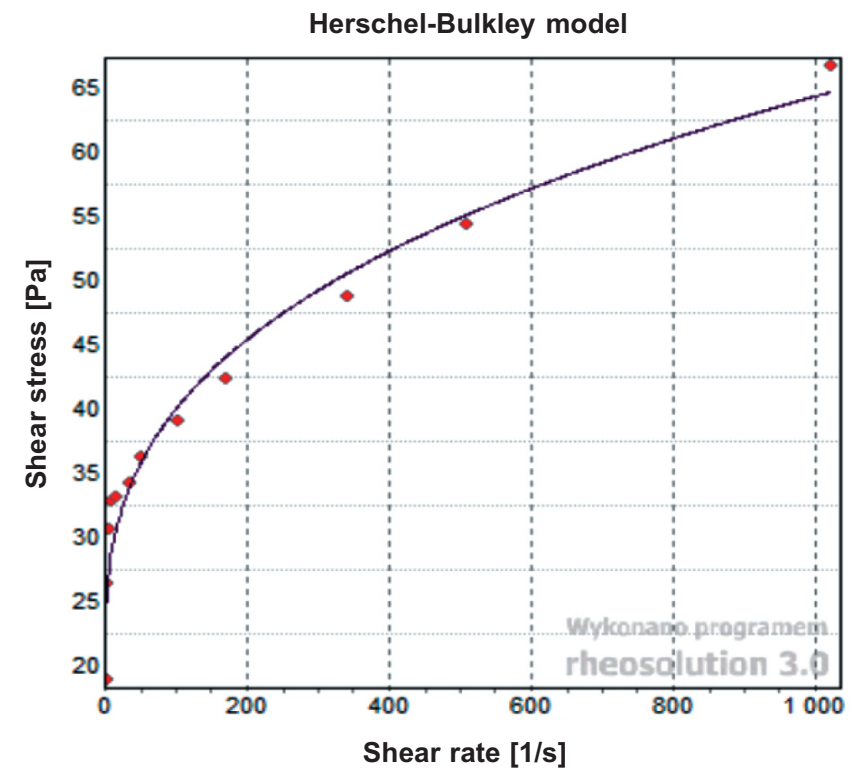

Fig. 4. Rheological model of the HDD Mud 2-1

with $4.0 \%$ concentration $(\mathrm{w} / \mathrm{w})$

\section{INFLUENCE OF HYDRATION INHIBITOR (KCI) ON TECHNOLOGICAL PARAMETERS OF HDD MUD}

Technological parameters of the selected mud with addition of inhibitor $(\mathrm{KCl})$ in concentration of $0.0-7.0 \% \mathrm{w} / \mathrm{w}$ were studied. Test outcome is presented in Figure 5. 

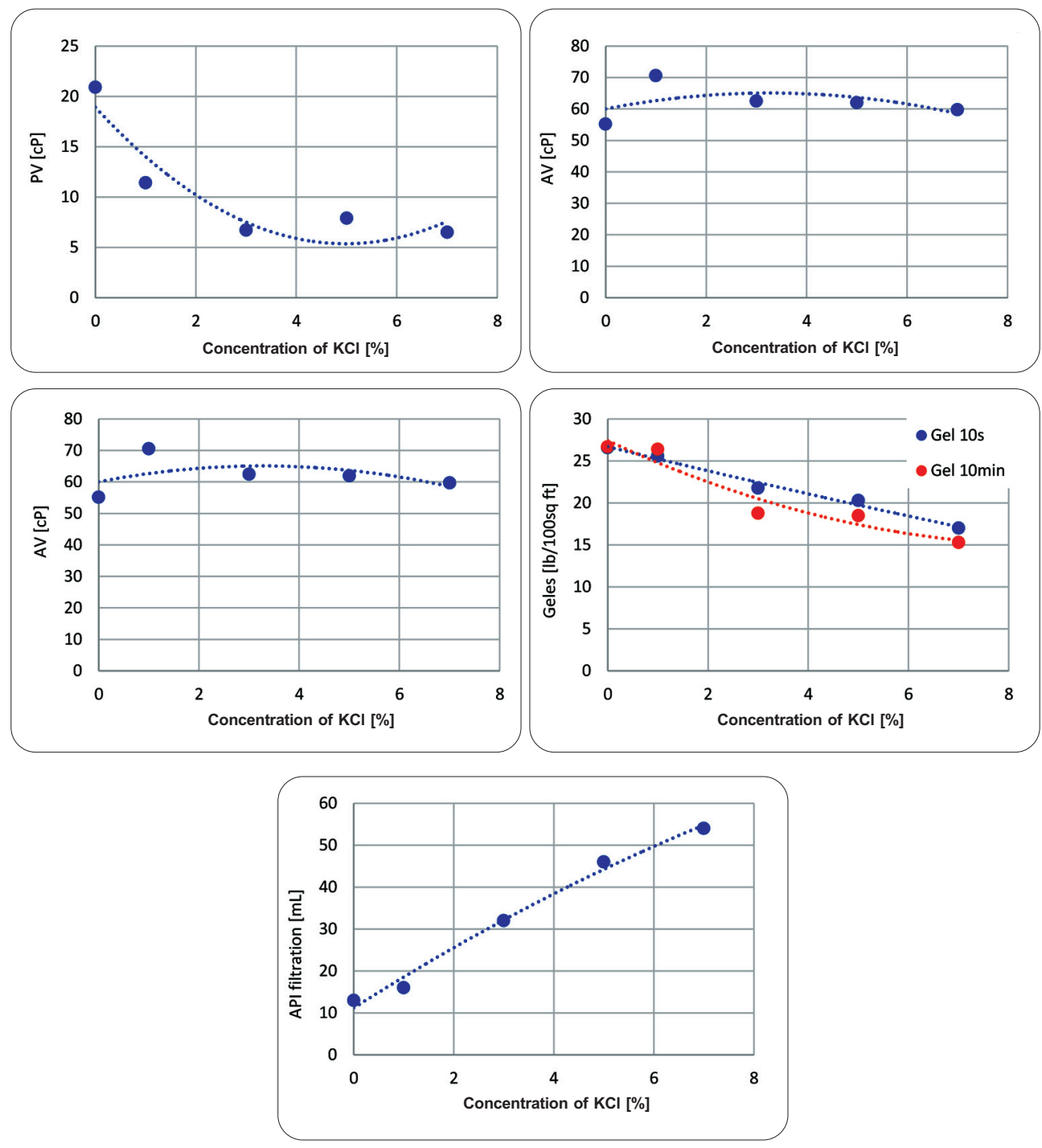

Fig. 5. Dependence of HDD Mud 2-1 technological parameters on $\mathrm{KCl}$ concentration

\section{INFLUENCE OF PROTECTIVE COLLOIDS ON TECHNOLOGICAL PARAMETERS OF THE HDD MUD}

Technological parameters of selected mud with addition of different protective colloids were tested. Following reagents were used in the studies: modified starch in concentration of $0.2 \%$ and $0.4 \% \mathrm{w} / \mathrm{w}, \mathrm{XCD}$ biopolymer in concentration of $0.05 \% \mathrm{w} / \mathrm{w}$ and low 
viscosity polyanionic cellulose in concentration of $0.2 \% \mathrm{w} / \mathrm{w}$. Best parameters were found for the mud with addition of PAC LV and this colloid was applied in the further studies. Technological parameters of HDD mud with PAC LV addition are shown in Table 2. Rheological model of HDD Mud 2-2 is presented in Figure 6.

Table 2

Formula and technological parameters of the HDD Mud 2-2

\begin{tabular}{|c|c|c|c|c|}
\hline Mud HI & $2-2$ & & gical paran & \\
\hline & & Density & 1.05 & {$\left[\mathrm{~g} / \mathrm{cm}^{3}\right]$} \\
\hline & & Plastic viscosity & 15.9 & {$[\mathrm{cP}]$} \\
\hline HDD Mud 2 & $4.0 \%$ & Apparent viscosity & 33.4 & {$[\mathrm{cP}]$} \\
\hline 1 HC & $0.2 \% 0$ & Yield Point & 16.8 & {$\left[\mathrm{lb} / 100 \mathrm{ft}^{2}\right]$} \\
\hline & & Geles & 11.8/17.7 & {$\left[\mathrm{lb} / 100 \mathrm{ft}^{2}\right]$} \\
\hline & & API filtration & 14 & {$[\mathrm{~mL}]$} \\
\hline
\end{tabular}

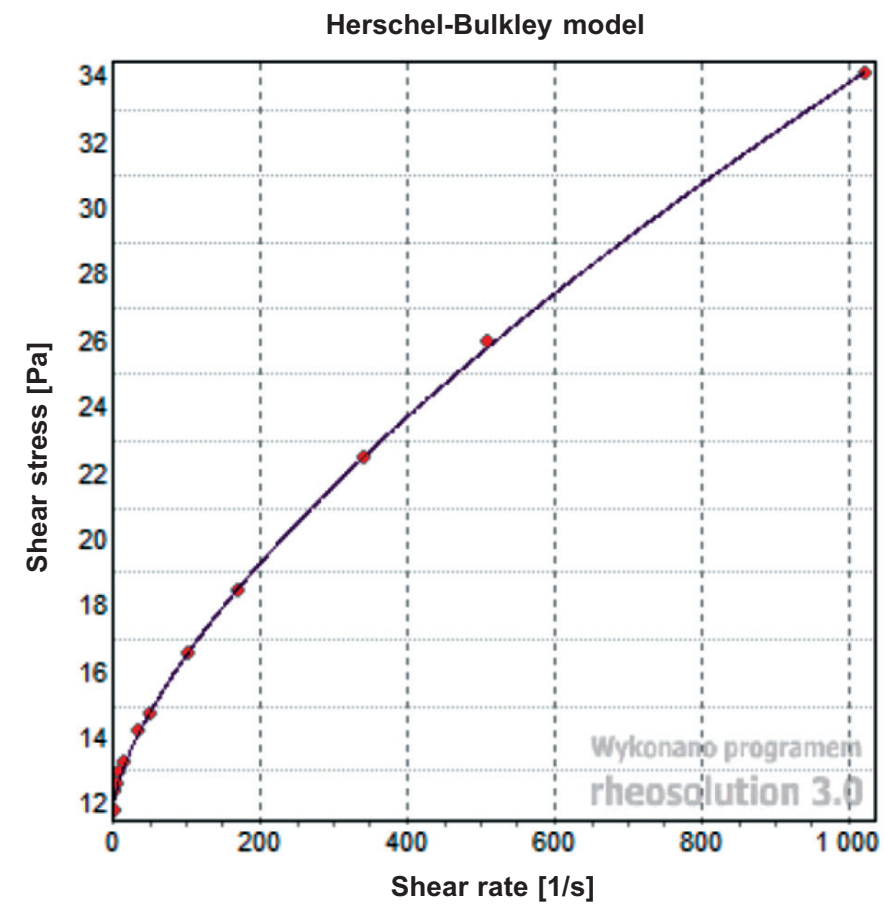

Fig. 6. Rheological model of the HDD Mud 2-2 


\section{INFLUENCE OF HYDRATION INHIBITOR ON TECHNOLOGICAL PARAMETERS OF THE HDD MUD WITH PROTECTIVE COLLOID ADDITION}

There were undertaken tests of technological parameters of the developed mud. First, parameters were measured directly after mud preparation and then after period of $24 \mathrm{~h}$. Formulas and technological parameters of studied muds are presented in Table 3 and 4. Rheological parameters are shown in Figure 7.

Table 3

Formula and technological parameters of the HDD Mud 2-3

\begin{tabular}{|c|c|c|c|c|}
\hline \multicolumn{2}{|c|}{ Mud HDD Mud 2-3 } & \multicolumn{3}{|c|}{ Technological parameters } \\
\hline \multirow{6}{*}{$\begin{array}{l}\text { HDD Mud } 2 \\
\text { PAC LV } \\
\mathrm{KCl}\end{array}$} & \multirow{6}{*}{$\begin{array}{l}4.0 \% \\
0.2 \% \\
7.0 \%\end{array}$} & Density & 1.05 & {$\left[\mathrm{~g} / \mathrm{cm}^{3}\right]$} \\
\hline & & Plastic viscosity & 8.8 & [cP] \\
\hline & & Apparent viscosity & 21.5 & {$[\mathrm{cP}]$} \\
\hline & & Yield Point & 12.2 & {$\left[\mathrm{lb} / 100 \mathrm{ft}^{2}\right]$} \\
\hline & & Geles & $10.1 / 13.0$ & {$\left[\mathrm{lb} / 100 \mathrm{ft}^{2}\right]$} \\
\hline & & API filtration & 17 & {$[\mathrm{~mL}]$} \\
\hline
\end{tabular}

Table 4

Formula and technological parameters of the HDD Mud 2-3 after $24 \mathrm{~h}$

\begin{tabular}{|l|lccc|}
\hline \multicolumn{2}{|c|}{$\begin{array}{c}\text { Mud HDD Mud 2-3 } \\
\text { after 24h }\end{array}$} & \multicolumn{3}{|c}{ Technological parameters } \\
\hline \multirow{4}{*}{ HDD Mud 2 } & $4.0 \%$ & Density & 1.05 & {$\left[\mathrm{~g} / \mathrm{cm}^{3}\right]$} \\
\cline { 3 - 5 } PAC LV & $0.3 \%$ & Plastic viscosity & 11.7 & {$[\mathrm{cP}]$} \\
\cline { 3 - 5 } KCl & $7.0 \%$ & Apparent viscosity & 24.2 & {$[\mathrm{cP}]$} \\
\cline { 3 - 5 } & & Yield Point & 12.0 & {$\left[\mathrm{lb} / 100 \mathrm{ft}^{2}\right]$} \\
\cline { 3 - 5 } & & Geles & $10.7 / 12.6$ & {$\left[\mathrm{lb} / 100 \mathrm{ft}^{2}\right]$} \\
\cline { 3 - 5 } & & API filtration & 16 & {$[\mathrm{~mL}]$} \\
\hline
\end{tabular}


a)

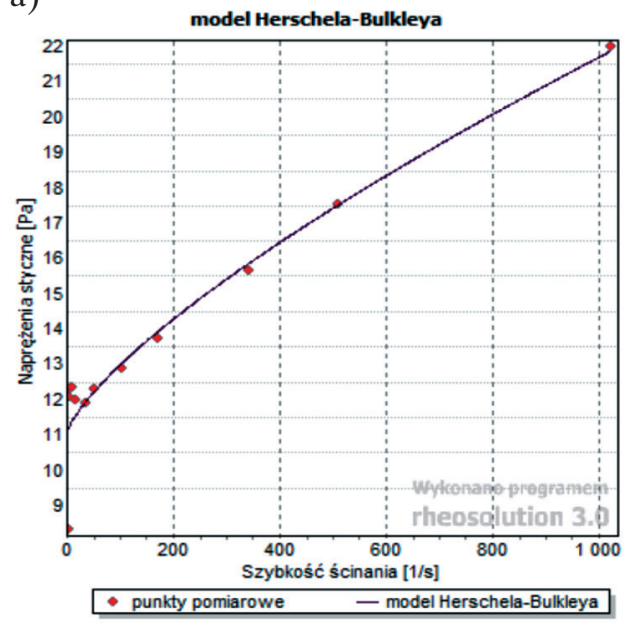

b)

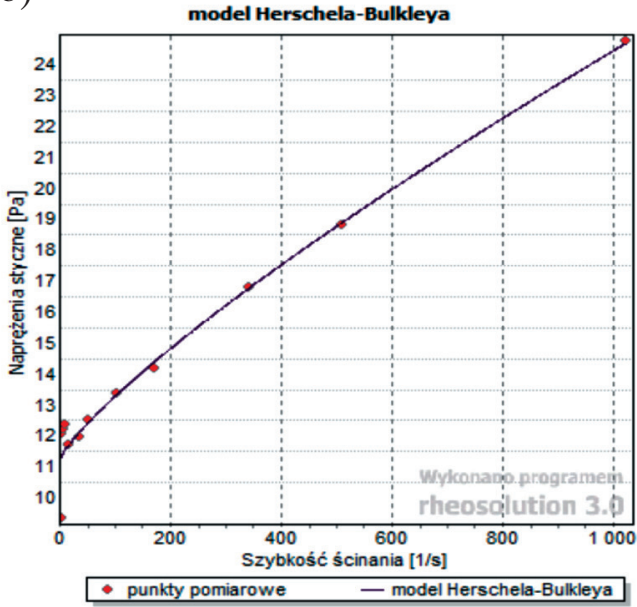

Fig. 7. Rheological model of the HDD Mud 2-3: a) after 15 min; b) after $24 \mathrm{~h}$

\section{INFLUENCE OF DEVELOPED MUD ON QSE PELLETS SWELLING}

Furthermore, influence of the developed mud on clay pellets swelling was investigated. Test results are given in Figure 8.
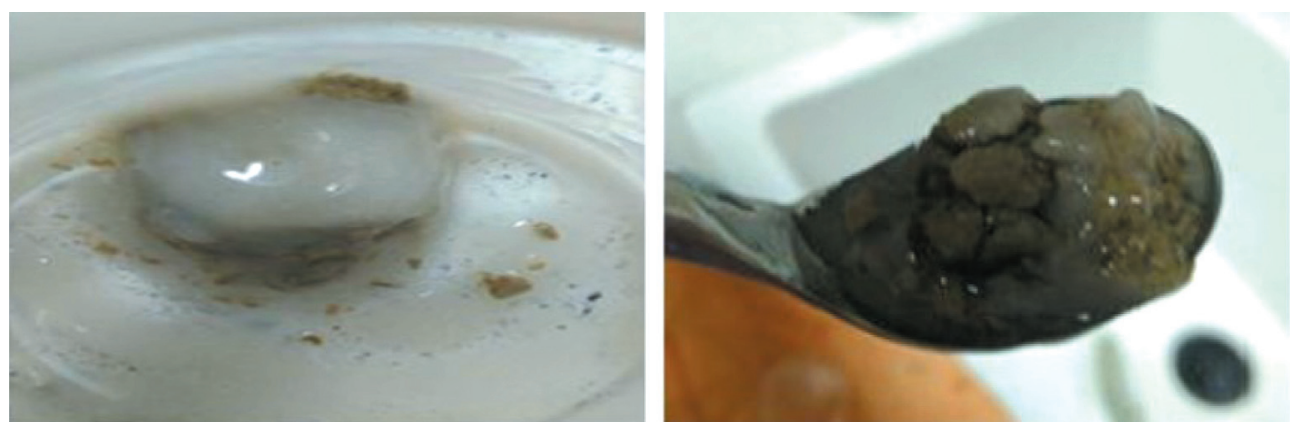

Fig. 8. Condition of the QSE Pellets after swelling test

\section{INFLUENCE OF DEVELOPED MUD ON LINEAR SWELLING OF CLAY ROCKS (LST)}

Linear swelling tests were performed for the developed mud. The outcome is presented in Figure 9. 


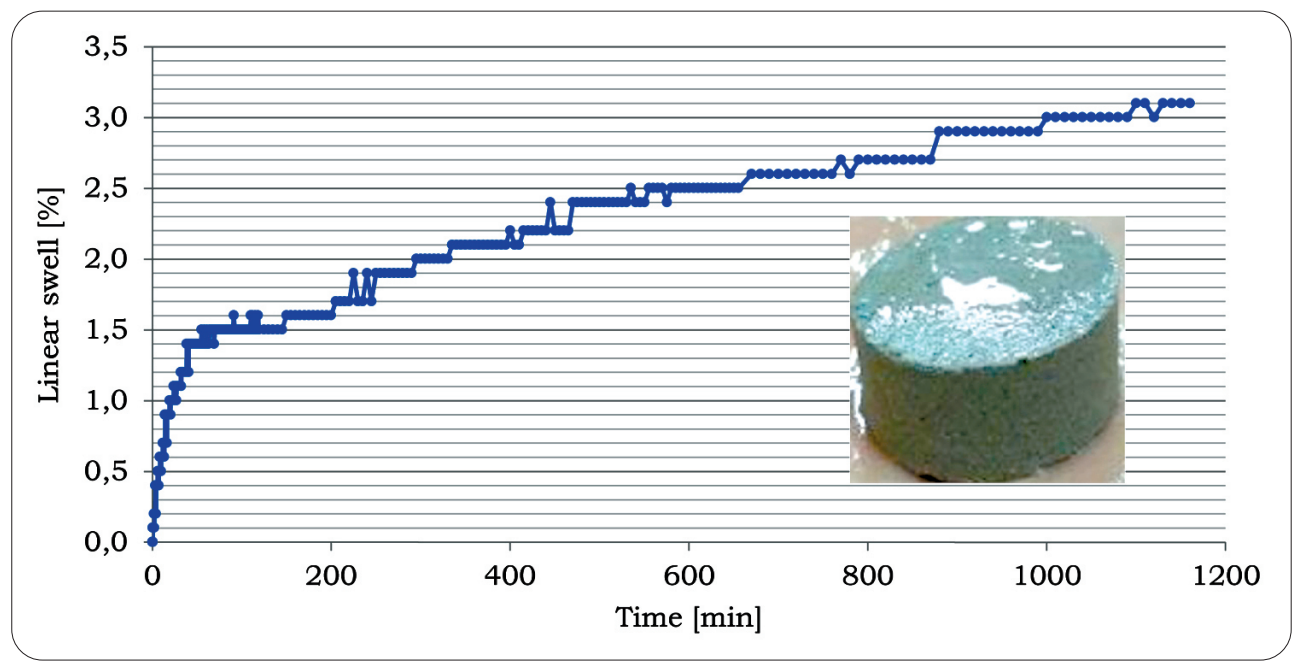

Fig. 9. Linear swelling test (LST) and condition of the sample after test

\section{DISCUSSION OF RESEARCH RESULTS}

In the framework of preliminary research, technological parameters of base muds, in concentration range of $2.5-4.0 \% \mathrm{w} / \mathrm{w}$, were tested. Studied muds are widely used in industrial practice for Horizontal Directional Drilling (HDD).

Undertaken tests showed increase of rheological properties and decrease of filtration with concentration growth of drilling fluid marked as HDD Mud 2 (Fig. 3). HDD Mud 2 with concentration of $4 \% \mathrm{w} / \mathrm{w}$ was selected for further tests (Tab. 1), subsequently rheological model of this mud was prepared (Fig. 4). It was recognized that studied mud is best described with Herschel-Bulkley model.

On the ground that mud is intended for drilling through clay rocks, it was decided to apply clay rock hydration inhibitor in mud formula in form of potassium chloride $(\mathrm{KCl})$ which contains potassium ion $\left(\mathrm{K}^{+}\right)$. Next, influence of potassium chloride addition on the technological parameters of base mud HDD Mud 2 was examined. Potassium chloride was applied in concentration range of $0.0-7.0 \% \mathrm{w} / \mathrm{w}$.

Based on carried out tests (Fig. 5), it can be observed that addition of potassium chloride negatively influences technological parameters of the base mud and leads to coagulation phenomenon, what is evidenced by both: significant increase of filtration and filter cake thickness. Application of ionic inhibitor in form of $\mathrm{KCl}$ into unmodified mud was found not effective. Due to this, it was decided to add protective colloid in mud formula.

Following, tests of technological parameters of the base mud influenced by three polymers were performed. Starch polymer in two concentrations of $0.2 \%$ and $0.4 \% \mathrm{w} / \mathrm{w}$, 
biopolymer XCD in concentration of $0.05 \% \mathrm{w} / \mathrm{w}$ and low viscosity polyanionic cellulose in concentration of $0.2 \% \mathrm{w} / \mathrm{w}$ were tested. Best results were obtained for the mud with addition of PAC LV, hence this colloid was applied for further studies (Tab. 2). The most correlated rheological model describing developed mud is Herschel-Bulkley model (Fig. 6).

In the subsequent stage of the studies, hydration inhibitor in form of potassium chloride with $7 \%$ concentration w/w was added to the HDD Mud 2-2. Conducted tests showed that developed HDD Mud 2-3 possess good rheological properties and low filtration. Mud is stable in time and its parameters do not change substantially in time period of $24 \mathrm{~h}$.

Last stage of the project consists of examination of developed mud inhibiting properties. Undertaken tests of QSE Pellets (clay samples) swelling showed that developed mud significantly limits test pellets swelling. It was noted $70 \%$ increase of volume for pellet conditioned in inhibited mud (HDD Mud 2-3) and 360\% for base mud (Fig. 8). As a result of the performed observations it was found that pellet is gluey and after pressing disintegrates.

Furthermore, linear swell tests of clays collected from boreholes drilled by HDD technique were conducted. Test outcomes (Fig. 9) showed high hydration inhibition effectiveness of developed mud. Swell of the sample reached just 3.1\% for inhibited mud and $11.7 \%$ for base mud. It has been found in the course of observations that clay sample is hard, although gluey.

\section{CONCLUSIONS}

During the studies, mud for Horizontal Directional Drilling, inhibited by potassium chloride, was developed. Mentioned mud is characterized by good technological parameters.

QSE Pellets and LST tests confirmed very high inhibiting properties of the developed mud. However, glutinosity of the clay samples does not permit recommendation of potassium chloride application as hydration inhibitor in Horizontal Directional Drilling.

\section{REFERENCES}

[1] Wysocki S., Wiśniowski R., Nowak W., Gaczoł M.: Płuczki wiertnicze na bazie superabsorbentów hydrożelowych do inżynieryjnych przewiertów kierunkowych. Przemysł Chemiczny, 96/5, 2017, s. 956-959.

[2] Osisanya S.O., Chenevert M.E.: Physics-Chemical Modelling of Wellbore Stability in Shale Formations. Annual Technical Meeting, June 12-15, Calgary, Alberta, 1994. 
[3] Dugan G.: Clay: Getting Out of a Sticky Situation. National Driller, February 2011. http:/www.cetco.com/DesktopModules/Bring2mind/DMX/Download.aspx?Command $=$ Core_Download $\&$ PortalId $=0 \&$ EntryId $=4342$ [access: 01.03.2018].

[4] Bland R., Pessier R., Isbell M.: Balling in Water-based Muds. 2001 AADE National Technical Conference, Houston, Texas, March 27-29 2001.

[5] Dugan G.: For HDD Drillers, Drilling Fluids Returns a Welcome Sight. National Driller, March 2015.

https://www.nationaldriller.com/articles/89921-for-hdd-drillers-drilling-fluids-returnsa-welcome-sight; [access: 01.03.2018].

[6] Schlumberger Self Learning Course, Stuck-Pipe Prevention. Sugar-Land Learning Center, 1999.

[7] Bielewicz D.: Ptyny wiertnicze. Wydawnictwa AGH, Kraków 2009.

[8] http://www.glossary.oilfield.slb.com/ [access: 01.03.2018].

[9] API RP 13B-1, $3^{\text {rd }}$ ed., December 2003.

[10] Skrzypaszek K.: Program „rheo solution” jako komputerowe narzędzie doboru modelu reologicznego cieczy wiertniczych. Oficyna Wydawnicza Politechniki Wrocławskiej, Wrocław 2004. 